\title{
MANAGEMENT OF ENDOCRINE DISEASE Growth and growth hormone therapy in short children born preterm
}

\author{
Margaret Cristina da Silva Boguszewski and Adriane de Andre Cardoso-Demartini \\ Department of Pediatrics, Endocrine Division (SEMPR), Federal University of Paraná, Curitiba, Brazil
}

Correspondence should be addressed to M C da Silva Boguszewski Email margabogus@uol.com.br

\begin{abstract}
Approximately 15 million babies are born preterm across the world every year, with less than 37 completed weeks of gestation. Survival rates increased during the last decades with the improvement of neonatal care. With premature birth, babies are deprived of the intense intrauterine growth phase, and postnatal growth failure might occur. Some children born prematurely will remain short at later ages and adult life. The risk of short stature increases if the child is also born small for gestational age. In this review, the effects of being born preterm on childhood growth and adult height and the hormonal abnormalities possibly associated with growth restriction are discussed, followed by a review of current information on growth hormone treatment for those who remain with short stature during infancy and childhood.
\end{abstract}

\section{Introduction}

Preterm birth is defined by the World Health Organization (WHO) as birth before 37 completed weeks of gestation or fewer than 259 days since the first day of a woman's last menstrual period (1). Of the 135 million live births worldwide in 2010, WHO estimates that 14.9 million babies were born prematurely, representing an increasing burden with a preterm birth rate of $11.1 \%$ (2). The risk of preterm birth is high for both the poorest and the richest countries. Approximately $60 \%$ of all preterm births worldwide occurred in sub-Saharan Africa and South Asia. However, of the 1.2 million estimated to occur in highincome regions, more than 0.5 million $(42 \%)$ occur in the United States (2). In England and Wales, it is estimated that 53000 infants were born preterm in 2010 (3). The causes of prematurity differ among countries (3), with the increment in many high-income countries attributed to multiple gestation and assisted conceptions due to treatment for sub-fertility (4). The survival rate also varies among countries due to the differences in basic care (5), with preterm birth considered one of the major causes of death before 5 years of age (2).

The measurement of gestational age (GA) indicates the length of gestation counted in days or weeks, from the first day of the last menstrual cycle, except for women undergoing assisted reproduction techniques. The term date, or 40 weeks (280 days), is calculated using the

\section{Invited Author's profile}

Margaret C S Boguszewski MD, PhD, is a Professor of Pediatric Endocrinology in the Department of Pediatrics and Chair of the Transition Endocrine Clinic at the Endocrine Division (SEMPR), Federal University of Parana, Curitiba, Brazil. Her research focuses on growth and puberty, particularly in children born preterm and children born small for gestational age.

() 2017 European Society of Endocrinology Printed in Great Britain

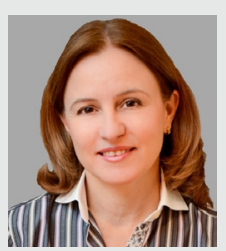


Naegele's rule, which adds seven days to the first day of the last menstrual period (LMP) and, to this date, sum nine months assuming a menstrual cycle of 28 days and ovulation in the 14th day (6). However, in many pregnancies, LMP is unknown or menstrual cycles are irregular. In these cases, measurements of the embryo or fetus obtained by ultrasonography performed up to 13 weeks and 6 days after conception are accurate to determine or confirm the GA (7). In case of assisted reproduction, the expected date of birth is calculated from the day of technical implementation. In case of in vitro fertilization, from the day of embryo transfer to the uterus (7). After birth, GA can be estimated by physical examination and neurological maturity of the newborn (8).

Preterm birth can be subdivided on the basis of GA, with extremely preterm (EPT) occurring at less than 28 weeks of GA, very preterm (VPT) from 28 but less than 32 weeks and moderate preterm (MPT) occurring from 32 and less than 37 completed weeks of gestation. MPT can be subdivided, being late preterm those born between 34 and 36 weeks and 6 days (9). The majority of the infants born prematurely, about $84 \%$ or 12.5 million, are moderate premature (10). In addition to this definition, studies performed before antenatal ultrasound became a routine for evaluation of GA considered infants as extremely low birth weight (ELBW), if weight was lower than $1000 \mathrm{~g}$, and very low birth weight (VLBW), if lower than $1500 \mathrm{~g}$. The use of birth weight as a selection criterion had the disadvantage to include, in the same study group, more mature children born small for GA (SGA) and preterm infants born appropriate for GA (AGA) (11). Neonatal survival improves with an increase in GA and weight at birth (10). Lifelong morbidities among survivors include cerebral palsy, intellectual impairment, chronic lung disease and vision and hearing loss (3). Increased blood pressure, accelerated weight gain and growth failure are also among the comorbidities $(2,12$, 13). In this review, we will highlight current information on growth in children born prematurely, mainly referring to publications with preterm classification based on GA; the hormonal abnormalities possible associated with lack of catch-up growth after the first months of life and discuss the potential treatment with recombinant human growth hormone (rhGH) for those who remain with short stature during infancy and childhood.

\section{Preterm growth charts}

With the advances in neonatal care during the last decades, the perspectives of growth of children born prematurely changed. The growth charts used to monitor their growth also had to improve. Nowadays, different types of growth charts are available for formerly preterm infants. The intrauterine growth charts are based on measurements of infants with different GA, the fetal growth charts are constructed with fetal measurements obtained by ultrasound and the postnatal growth curves are constructed with measurements of infants during the hospitalization period. Significant differences are observed between these reference charts for evaluation of postnatal growth, especially with regard to head circumference (HC) (14).

The intrauterine growth charts are the most recommended for monitoring growth of preterm infants. At least 25 reference charts of this type are available (15). One of their disadvantages is the fact that the preterm infant usually is smaller than the healthy reference not exposed to the extrauterine environment $(16,17$, 18). Furthermore, after preterm birth, weight gain and longitudinal growth are more intense close to term (3740 weeks), whereas weight and length gain are already decreasing at the end of a normal full-term gestation (19). In 2003, Fenton put together data of three different populations and developed an intrauterine growth chart starting at 22 weeks of gestation with a scale of weight every $100 \mathrm{~g}$. The CDC-2000 growth data between 40th and 50th weeks after conception were added resulting in a fetal-neonatal growth chart, which facilitates the adjustment of growth to prematurity, recommended up to 3 years of age (20). A new version was released in 2013 with data from six countries. It is now a gender-specific growth chart from 22-week gestation until 10 weeks after term and aligns with the WHO-2006 growth charts allowing a longer period of growth follow-up (19).

Fetal growth charts are constructed from fetal measurements obtained by ultrasonography. Theoretically, they reflect the expected growth for each gestational age without the effects of prematurity. Their disadvantage is the sensitivity of ultrasonography to assess fetal weight, especially during the first weeks of gestation $(15,21$, $22,23)$. The postnatal growth charts are longitudinal and constructed from sequential measurements of preterm infants, considering the delay of the early extrauterine growth (15). An example is the gender-specific curves from 24th week up to 2 years of corrected age from Sweden (24).

More recently, customized growth charts adjusted for physiological variables such as maternal weight and height, parity, ethnicity and smoking were created (25). The INTERGROWTH-21st Project, a prospective international multiethnic study, was launched to complement the 
WHO 2006 (26) by developing international standards for fetuses, newborn infants and postnatal growth of infants born prematurely (27). Data from pregnancies of low obstetric risk from Brazil, China, India, Italy, Kenya, Oman, United Kingdom and United States were included. The authors suggested that using multiple populations from several countries would enhance the diversity in the biological characteristics, such as parental size and maternal weight gain during pregnancy, as well as external factors influencing fetal growth (27). The resulting growth charts were recommended for preterm infants born after 33-week gestation to 6 months of corrected age for prematurity (28). Currently, no large randomized trials are available showing the benefits of customised growth charts (29).

\section{Early growth in children born prematurely}

Several factors might influence intrauterine growth, such as genetic, environmental and hormonal factors, placental development, supply of nutrients and maternal health (30). In uncomplicated pregnancies, the fetus has a high growth rate that will not be repeated in any other stages of life. With premature birth, babies are deprived of this intense intrauterine growth phase. In addition, preterm birth might disrupt the normal growth regulation of infancy.

The American Academy of Pediatrics recommends that infants born prematurely should grow similarly to the fetus with the same GA. This recommendation refers mainly to weight gain, although length and head circumference are also important, the latter associated with neurological outcome (31). Typically, weight loss is expected during the first days of life, similar to the initial weight loss observed in babies born at term. However, in preterm infants, the intensity of this loss is associated with GA, birth weight and time required to achieve full enteral nutrition (32). After this initial period, a transition phase should start, with stabilization of weight and a slight increase in length, followed by the catch-up period, when growth rate exceeds that expected for the fetus with the same GA. The last phase is characterized by growth rate comparable to that of children born at term (33, $34,35)$. When growth restriction remains during early postnatal period with growth rates lower than expected, it is stated that the preterm infant is suffering extrauterine growth restriction (EUGR) (36, 37), more common among extremely and very preterm infants (38). There is no consensus on definition of EUGR. One definition considers a decrease of 2.0SD or more in weight and/or length between birth and 36 weeks after conception (39). Less strict definitions are also used by pediatricians (36, $37,40)$. In addition to time of gestation, other factors were associated with increased risk of impairment of early growth, including male gender $(37,41)$, history of maternal hypertension (42), bronchopulmonary dysplasia (BPD) $(37,43,44)$, necrotizing enterocolitis (37), postnatal use of corticosteroids $(37,45,46)$, intra-uterine growth retardation (IUGR) or SGA birth (47), high levels of total alkaline phosphatase during the neonatal period (42), EUGR $(48,49)$ and feeding difficulties $(50,51)$.

\section{Childhood outcome}

The first year of life is a critical period for children born prematurely. Hospital stay can be long and prone to morbidities such as lung diseases, intraventricular hemorrhage, necrotizing enterocolitis, late-onset sepsis, among others (52). Weight and height gain is associated with the age of achievement of full enteral feedings and occurrence of EUGR $(36,37,39)$. Those who survive to hospital discharge are shorter and lighter than fullterm peers, despite the intense catch-up growth they may have had (53). Approximately $80 \%$ of formerly preterm children exhibit growth recovery during the first 2 years of life $(33,35,54,55,56,57)$, with height percentile appropriated for genetic potential between 6 and 12 months of life. After 2-3 years of age, height gain correlates with parent's height $(55,58,59,60,61,62)$. At 3 years of age, approximately $80 \%$ reaches the normality for head circumference and $70 \%$ for weight. The lack of recovery is also associated with low socioeconomic status (63), long period of parenteral nutrition, neurological disorders, chronic respiratory diseases, EUGR and parental short stature $(37,41,47,64,65)$. This review will focus on growth after 2 years of age, when a more stable healthy condition is expected with less hospital readmissions.

\section{Infancy and childhood growth}

Despite the majority of the preterm infants being MPT, much of the research to date on growth of infants born prematurely has focused on those born with less than 32 weeks of GA. More extreme the limit of viability, more the effects of preterm birth are confounded with those of intrauterine and extrauterine growth restrictions. In the extreme lower limit of weight at birth, RiegerFackeldey et al. (66) reported the follow-up of 19 children 
with a birth weight $<500 \mathrm{~g}$ who received immediate life support, all EPT, 18 born SGA. Seven of them caught up in length by 5 years of age, but all were below the 25th percentile in height by this age. Another study, the EPICure cohort, evaluated 241 children born with GA $\leq 25$ weeks (67). At 6 years of age, children born EPT were still leaner, shorter and have a smaller head circumference than their peers, with some catch-up growth observed from 30 months to 6 years of age. Birth weight for GA was strongly associated with growth outcome at 6 years. Follow-up to 11 years of age of 83 EPT children born in the 1990s was described by Farooqi et al. (54). Their mean GA was 24.6 weeks and mean birth weight was $765 \mathrm{~g}$, six were born SGA and three were on GH treatment. A marked drop in weight SDS was observed to 3-month corrected age, when weight began to increase reaching the mean of the reference at approximately 11 years of age. Similar pattern was observed for height, with a significant increase in height SDS between the ages of 3 months of corrected age for prematurity and 3 years and between ages 7 and 11 years. At 11 years of age, EPT girls were $3.1 \mathrm{~cm}$ and the EPT boys $5.7 \mathrm{~cm}$ shorter than controls. Unfortunately, they did not have information on pubertal development; pubertal growth spurt could explain in part their later increase in height.

Among the VPT children, a French population-based study evaluated growth outcome to 5 years of age in 1597 children born in the late 1990s (68). At 5 years, $5.6 \%$ had short stature and 6 children received rhGH treatment between 2 and 5 years of age. Of the 118 children with short stature at 2 years, 55 (47\%) remained with short stature at 5 years, whereas from the 276 with height between -1 and -2 SD at 2 years, 26 (9\%) became $\leq-2$ SD at 5 years. The highest incidence of short stature at 5 years was observed among preterm born AGA with EUGR, whereas the incidence among preterm born SGA did not change from 2 to 5 years, suggesting that catch-up growth in SGA children occurs mainly during the first 2 years of life, as previously reported (69). Knops et al. (58) demonstrated that VPT children born AGA had normal stature at 10 years of age, whereas those born VPT and SGA were lower even after correction for target height (AGA $=0.0$ SDS; SGA $<32$ weeks $=-0.29$ SDS; SGA $\geq 32$ weeks $=-0.13$ SDS). Catch-up growth was especially seen in the children born SGA with a fast weight gain during the first three months of life. At a mean age of 8 years, Hack et al. (41) found height SDS of -2.6 for boys born with VLBW, significantly lower than the control group born full-term. VLBW girls were leaner but did not differed significantly in height compared with the control group. Ford et al. (64) observed an acceleration of growth between 8 and 14 years of age in teenagers born with BW $<1500 \mathrm{~g}$ and $\mathrm{GA}<30$ weeks, suggesting a late catch-up growth. Most of them had weight and height higher than -2.0 SDS, but all were lower and lighter than the control group born at term and AGA. The risk of short stature increased with maternal height $\leq 160 \mathrm{~cm}$, GA $<29$ weeks, birth length $<-2$ SD and use of corticosteroids. The influence of being born SGA, maternal size and comorbidities on height of formerly preterm children at 5 years or older has been reported before $(58,59,60$, 62). Trebar et al. (59) evaluated 1320 children born with VLBW at 5-6 years of age, GA from 22 to 38 weeks, 730 born SGA and 590 born AGA. At age 6, 8.3\% AGA and $13.4 \%$ SGA children were short $(<-2$ SDS). The most important predictors of height at 5/6 years of age were height at 1 year of age, the difference in height between ages 1 and 2 and midparental height SDS. Despite having children born at term in their study, the majority were preterm with known GA. At 12 years of age, children born prematurely and SGA were shorter and leaner than children born full-term and AGA, without increment in height after 8 years of age, whereas preterm born AGA with neonatal comorbidities still presented some gain in height after 8 years of age (70). These studies reinforce the influence of size at birth on catch-up growth among preterm children.

When considering less premature infants, 1123 MPT children born between 2002 and 2003 in Netherlands were evaluated at the age of 4 years (71). Growth restraint was 2.5 times more prevalent in MPT than in term children; 32 boys (5.6\%) and 18 girls (3.8\%) were growth-restricted in height at this age. In a population-based study evolving 1414 late preterm infants (born between 34 and 36 weeks and 6 days) followed from birth to 3 years of age at the city of Kobe, Japan, the authors showed an incidence of $2.9 \%$ of short stature in the late preterm group, significantly higher than the $1.4 \%$ found in the term group. The risk for short stature was 4.5 -fold higher if the late preterm were born SGA (13). Figure 1 illustrates the growth trajectories that could occur in children born preterm based on the previous publications.

Regarding height at onset of puberty, data from adolescents born during the 1970s in Sweden showed that those born SGA were shorter at puberty onset with earlier menarche than the reference group, but neither age at puberty onset nor menarche was influenced by prematurity (72). In low birth weight children, including ELBW, despite being shorter and lighter than those born at term at the start of puberty, 


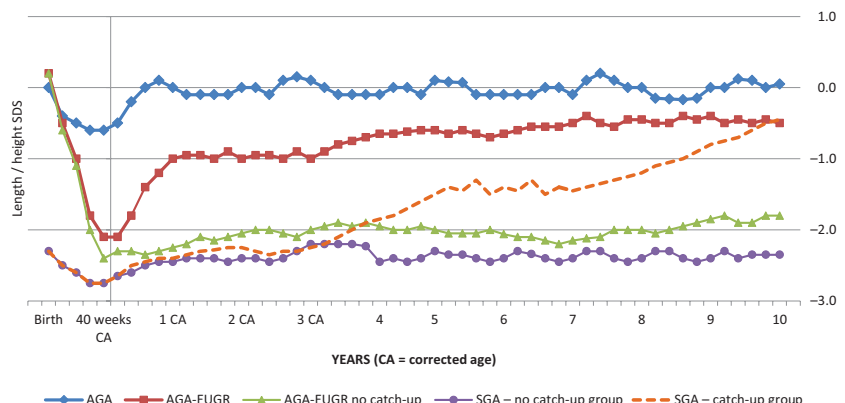

Figure 1

Growth from birth to 10 years in children born preterm. Five possibilities of growth trajectories are presented: AGA: Initial growth deceleration similar to babies born at term followed by a catch-up period and stabilization of growth. AGA - EUGR: More intense initial growth restriction followed by a catch-up growth that occurs before 3 years of corrected age. AGA EUGR no catch-up: No catch-up growth after the intense initial growth restriction. Growth resembles growth pattern of SGA children without catch-up growth. SGA - no catch-up: Preterm SGA children without catch-up growth. SGA - catch-up:

Preterm SGA with late catch-up growth, up to adolescence, but keeping lower height compared to peers born at term. AGA, appropriate for gestational age; EUGR, extrauterine growth restriction; SGA, small for gestational age.

previous reports did not find the difference in sexual maturity $(61,64,73)$. Sullivan et al. (70), using selfassessment evaluation, found that $60 \%$ of the boys and $50 \%$ of the girls in a group of 194 adolescents born prematurely were Tanner stage 0 at 12 years of age. Few had completed puberty at this age. More recently, data of VLBW children born between 1978 and 1985 were evaluated to adult height and compared with data from full-term born group (74). The study included VLBW born SGA (GA 29-35.6 weeks; birth weight 700-1499 g) and VLBW born AGA (GA 24.7-31.7 weeks; 600-1490 g). They all were shorter than controls during prepubertal years, as reported before. However, age at acceleration of growth velocity during puberty onset was earlier in both groups of VLBW, ten months earlier in VLBW AGA and 11 months earlier in VLBW SGA. Higher body mass index during prepubertal years was associated with an early growth spurt. Age at attaining adult height was also significantly lower. Age of puberty onset was in the normal range, and no difference was observed in age of menarche or voice change (74), reinforcing the need to carefully follow all growth period of formerly preterm children, from birth to maturity, in order to detect any acceleration of growth velocity that could suggest an early growth spurt. Brandt et al. (75) found a significant difference in age at menarche among SGA girls born preterm without catch-up growth and girls born full term (12.2 vs 13.4 years, $P<0.01)$. Difference was also significant when compared with preterm girls born SGA with postnatal catch-up growth (12.2 vs 13.6 years, $P<0.01$ ), suggesting the importance of catch-up growth in age of menarche. Age of menarche was also associated with lower GA (74).

Although puberty begins at a normal age, children born prematurely are more prone to an earlier onset of pubertal development, faster progression of puberty and earlier menarche relative to full-term and AGA children (74). A modest bone age delay at the onset of puberty and more rapid bone maturation during puberty has been reported, similar to SGA children $(76,77)$. Peak height velocity is reached at an earlier pubertal stage and lasts for a shorter period in children born prematurely $(74,76)$, increasing the risk of a shorter adult height. Rapid weight gain early in childhood might be associated with unfavorable growth outcome $(76,77)$.

Table 1 Risk factors for growth failure in children born preterm.

\begin{tabular}{lll}
\hline Period & Risk factors \\
\cline { 1 - 1 } Perinatal & $\begin{array}{l}\text { Intrauterine growth retardation } \\
\text { Neonatal }\end{array}$ & Male sex \\
& Gestational age $<32$ weeks (specially $<28$ weeks) \\
& Birth weight $<1500 \mathrm{~g}$ \\
& Birth length $<-2 \mathrm{SD}$ \\
& Small for gestational age \\
& Extrauterine growth restriction \\
& Bronchopulmonary dysplasia \\
& Metabolic bone disease of prematurity \\
& Necrotizing enterocolitis \\
& Postnatal corticosteroids use \\
& Long time in total parenteral nutrition \\
& Feeding difficulties \\
& Chronic respiratory diseases \\
& Cerebral palsy \\
& Neurodevelopment delay \\
Infancy & Feeding difficulties \\
& Lack or delay of catch-up growth \\
& Low target height \\
& Low socioeconomic status \\
Young age at onset of pubertal growth spurt \\
and fast progression of puberty \\
Lack or delay of catch-up growth \\
Low target height \\
Maternal short stature (specially $<160 \mathrm{~cm}$ ) \\
Low maternal education \\
Low socioeconomic status \\
Adolescence
\end{tabular}

For details, see References $(37,41,42,43,44,45,46,47,48,49,50,51,63$, $64,65,74)$. 


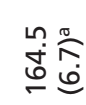

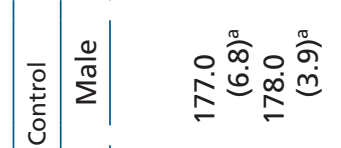

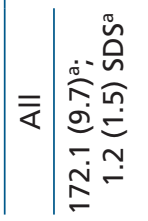

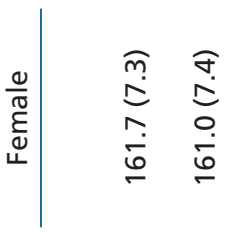

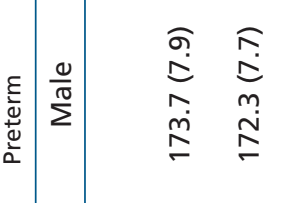

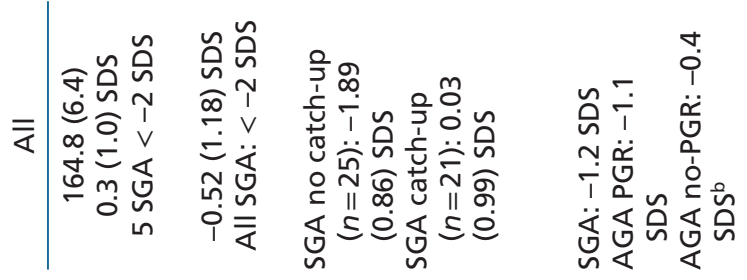

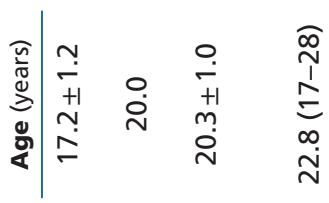

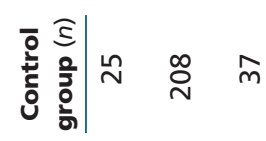

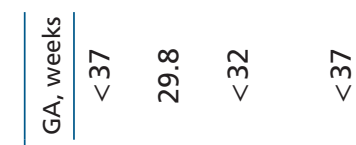

ร

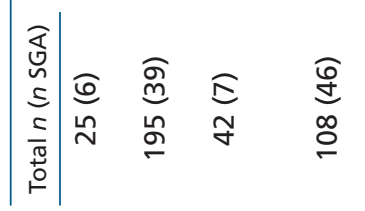

产|

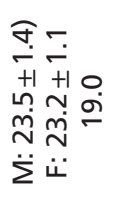

$\bar{m}$

$\stackrel{\infty}{\stackrel{\infty}{\Sigma}}$

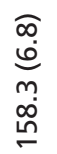

$\pi n$
$\stackrel{\pi}{0}$
0
$\stackrel{0}{5}$

$\stackrel{n}{v}$

은 윰

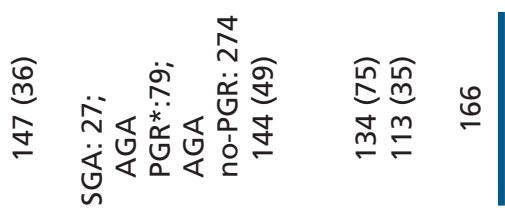

$\underset{\widehat{\infty}}{\widehat{\omega}}$

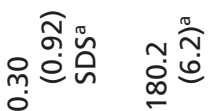

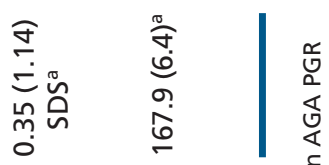

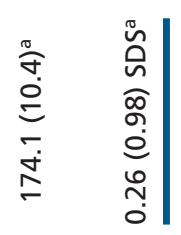

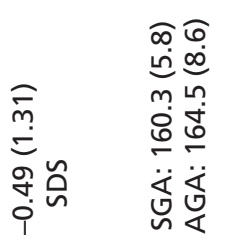

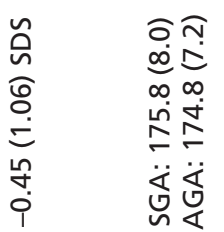

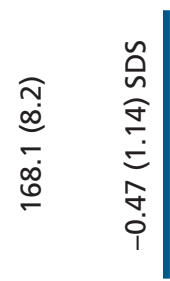

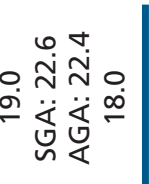

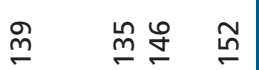

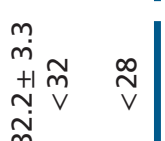

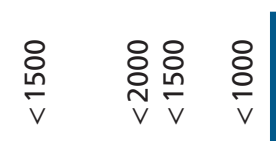
I 离 $\frac{2}{\square}$

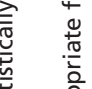
$\frac{10}{2}$ 离䓪 这 $\frac{\pi}{\pi}$ 䇋

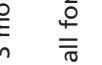
范 命 芯 v $\stackrel{n}{\widehat{v}}$ $\frac{\sqrt{2}}{\frac{\pi}{\pi}}$ $\sum^{\frac{1}{2}} \stackrel{\frac{\pi}{0}}{\frac{\pi}{0}}$ क्ष

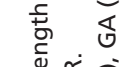
它

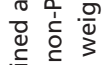

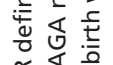
空全致 
Table 1 summarizes the risk factors for short stature in subjects born prematurely.

\section{Adult outcome}

Few studies are available on adult height in those born preterm (Table 2) $(41,57,74,75,78,79,80,81,82,83)$. Some are cohort studies with strict inclusion criteria and subjects followed from birth to adult height, but with the disadvantages of long-term studies, such as loss of follow-up. There are also cross-sectional populationlinkage studies, with data from birth linked to data in adult life, with the possibility of much larger samples (80).

In a nationwide population linkage study in Norway, birth records and adult height of 348706 young boys were evaluated, 15454 of them (4.5\%) born with GA from 26 to 36 weeks. Birth length was the best predictor of adult height. However, when stratified by GA, the relatively long infants born preterm became shorter adults compared with same-length infants born at term (12). In a cohort study in Germany (75) with the evaluation of 108 VLBW infants born from 1967 to 1978, almost 50\% had complete catch-up by adult age. The authors concluded that growth at earlier ages did not predict adult height due to a great intraindividual variability in growth patterns from birth to 6 years of age and to adulthood. GA ranged from approximately 28 to 35 weeks and could explain in part the variability in postnatal growth patterns. In Australia (84), a total of 42 ELBW subjects born after 1977 were followed from birth to 20 years of age. Catch-up growth was observed only at 14 years of age, during puberty. Two of the subjects received synthetic growth hormone $(\mathrm{GH})$, and by early adulthood, all had attained height consistent with their parents' height. The same group followed 225 consecutive EPT survivors born during 1991-1992 to 18 years of age (83). For this evaluation, selection criterion was based on GA. EPT children were shorter than controls at all ages from 2 to 18 years. At 18 years, $9 \%$ of the EPT were $<-2$ SD in height, against only one subject $(0.7 \%)$ born at term with short stature. Height at 2 years explained $50 \%$ of the variability in final height. The control group born at term was significantly taller than their median parental height, whereas the EPT subjects were slightly shorter than their parents.

Another way to evaluate outcome in infants born prematurely is to consider neonatal growth and the occurrence of EUGR in addition to GA. Finken et al. (57) evaluated 380 adolescents born VPT ( $<32$ weeks GA), 21\% of them born AGA and with EUGR, confirmed with measurements at 3 months of age. Their height near 19 years of age was compared with height of VPT
AGA without EUGR and with height of VPT born SGA. The AGA group with EUGR was characterized by a low GA, a high prevalence of respiratory distress, intracranial hemorrhage and glucocorticoid therapy. The prevalence of short stature at 5 years of age was close to $20 \%$ in both VPT SGA and VPT AGA with EUGR. In addition, height $<-2$ SD at the age of 5 years in these two groups points to a high risk $(\approx 90 \%)$ of short stature in adulthood. Their growth was compared with that described previously for SGA children born at term, suggesting that they could benefit from GH treatment. Hack et al. (41) evaluated 195 VLBW young adults at 20 years of age. Compared with control group, boys were leaner $(-0.35 \pm 1.25$ vs $0.53 \pm 1.06$ SDS $)$ and shorter $(-0.44 \pm 1.10$ vs $0.03 \pm 0.95$ SDS), 7\% with height $<-2.0$ SDS. Short stature at 20 years of age was associated with lower maternal education, lower maternal height and lower birth weight.

\section{Hormonal abnormalities}

It has been proposed that adverse exposures during fetal and early postnatal life lead to unfavorable programming effects $(85,86,87)$. In infants born prematurely, the period equivalent to the third trimester of gestation occurs extra-utero, with higher risk of alterations of the GH and insulin-like growth factor (IGF) system (88). Few and conflicting data are available on $\mathrm{GH}$ axis in formerly preterm children with short stature during infancy and childhood. Elevated circulating GH levels during neonatal period with low IGF-1 and low GH-binding protein (GHBP) concentrations were reported, suggesting immaturity of the $\mathrm{GH}$ receptor with less inhibitory feedback on hypothalamopituitary axis $(89,90)$. Association of IGF-1 levels with growth restriction and catch-up growth in the immediate postnatal period (91), low IGF-1- and IGF-binding protein 3 (IGFBP-3) concentrations $(88,92)$ with high IGF-2 during mid-childhood (88), normal IGF1, IGF-2, IGFBP-1 and GH-binding protein (GHBP) with high IGFBP-2 (93), and lower prolactin and higher IGF-1 levels than control at the start of puberty (94) were also reported. Normal response to IGF-1 generation test (95) was reported in short children at a mean age of 7 years, with no clear evidence of GH or IGF insensitivity, but with some suggestion of alterations of the IGF/IGFBP system. During the immediate postnatal period to 6 months postterm, IGF-1 levels were not associated with nutrient intake $(91,96)$. A highly significant influence of the genomic deletion of exon 3 of the GH receptor, d3-GHR isoform, on the postnatal growth pattern was also reported, with higher probability of postnatal catch-up growth in those 
who carry at least one GHRd3 allele. Children heterozygous or homozygous for GHRd3 also had higher serum levels of IGF-1 and IGFBP-3 (97). Recently, Guasti et al. evaluated fibroblast growth factor 21 (FGF21) serum concentrations during the first 5 weeks of life in VPT infants. They found an inverse association with linear growth but not with weight gain (98). High FGF21 level impairs linear growth by a mechanism involving direct inhibition of GH action on chondrocytes at the growth plate. This could be a reason for the GH resistance secondary to prematurity (98).

These results might reflect the heterogeneity of preterm birth, with possibilities of intra and extrauterine growth retardation and an immature fetal state of the GH/ IGF-1 axis during the early postnatal period with relatively low GHR expression. During mid-childhood and puberty, with more mature GH/IGF-I axis, alterations of the IGF/ IGFBP system might occur.

\section{Growth hormone treatment}

GH treatment was given to seven preterm infants born SGA from postnatal day 7 until a body weight of $2000 \mathrm{~g}$ was reached at postnatal week $7-8$ in an attempt to improve nutrition. No significant effects were observed on growth, body composition, net protein gain and glucose metabolism (99). Recently, VPT infants received recombinant human $\mathrm{GH}(0.03 \mathrm{mg} / \mathrm{kg} /$ day $)$ after birth. At 6 months of treatment, growth velocity, body weight, length and $\mathrm{HC}$ were significantly higher compared with those of the control group. Time to reach adequate oral feeding and time to restore birth weight were shorter and less EUGR was observed (100). IGF-1 and IGFBP-3 levels were not different at birth, with significantly higher concentrations at 3 and 6 months in the treatment group. The authors suggested that $\mathrm{GH}$ treatment regulates the preterm endocrine and metabolic state without severe adverse effects (100). No further studies with GH treatment at this early age were available at present time.

Studies on the effects of GH for treatment of short stature of different etiologies usually included children born prematurely, especially those involving children born SGA $(101,102)$. GH treatment was approved by the US Food and Drugs Administration in 2001 for children born SGA who fail to manifest catch-up growth by the age of 2 years. Approved GH dose was $0.070 \mathrm{mg} / \mathrm{kg}$.day. In Europe, treatment was approved by the European Agency for the Evaluation of Medical Products in 2003 with the dose of $0.035 \mathrm{mg} / \mathrm{kg}$.day for children older than 4 years of age. The consensus statement from the International
Societies of Pediatric Endocrinology and the Growth Hormone Research Society proposed that children born SGA with height below -2.5 SDS at the age of 2 years or with height below -2.0 SDS at the age of 4 years should be eligible for GH treatment (103). In the SGA studies, the preterm ones were often younger and shorter than the term ones, with height velocity SDS below zero, which reinforces that they were not presenting spontaneous catch-up growth $(104,105)$. de Kort et al. (104) evaluated a cohort of 392 short SGA children treated during 3 years with GH. The response to GH treatment was similar for both preterm and term short SGA groups. After 4 years of treatment, the effects of GH on metabolic and cardiovascular risk factors were similar between preterm and term SGA children, with no significant changes in glucose homeostasis and a decrease in blood pressure and fat mass in the preterm ones (104). Among very young short children born SGA (chronological age at the start of GH treatment from 2 to 4 years), those born prematurely received a higher GH dose and presented higher growth velocity during the first year of therapy (105).

Few studies in which only formerly preterm children were included are available to date. The first year growth response to GH treatment in short children born preterm (26-37 uncompleted weeks of GA) was demonstrated using information from a large international database of children treated with rhGH, including 1928 preterm AGA, 629 VPT AGA, 519 preterm SGA and 139 VPT SGA, all prepubertal and with different GH secretion status (106). Age at start ranged from 3 to 12 years, and all four groups presented a significant increase in height velocity and weight gain during the first year of GH treatment. Age at GH start, bone age and adjusted parental height were inversely associated with the first year growth response, whereas GH dose had a positive association. Gestational age and birth weight SDS had a weak correlation with the growth response only for the preterm born AGA. One year rhGH treatment of short children born with VLBW both AGA and SGA, showed similar increase in height velocity, height, weight and muscle strength in both groups, with increment of IGF-1 concentrations (107). Growth response and adult height could be predicted using prediction models independent of GH secretion status and size at birth $(108,109)$. Garcia et al. (110) evaluated the growth response with a relatively high GH dose $(0.066 \mathrm{mg} / \mathrm{kg} /$ day $)$ in very young SGA children born prematurely. They reported an increment of $1.3 \mathrm{SD}$ after the first year with a subsequent gain of $2.1 \mathrm{SD}$ for the 17 children who completed 2 years of GH treatment. These studies suggest that, when growth failure occurs 
and persists during infancy and childhood, children born prematurely might benefit from GH treatment.

\section{Conclusion}

Growth pattern of children born prematurely has unique characteristics. Weight loss is expected during the first days of life, followed by stabilization of weight and a slight increase in length. A catch-up period is further expected with growth rates comparable to that of children born at term. Approximately 70-80\% of children born preterm will have adequate height, weight and head circumference by 3 years of age. However, when growth restriction remains during infancy and childhood, children born prematurely are of increased risk of short stature. Growth failure may be compounded in the presence of intrauterine or extrauterine growth restrictions, extreme prematurity, bronchopulmonary dysplasia, necrotizing enterocolitis or metabolic bone disease of prematurity. Those who are short at 2 years of age are unlikely to reach normal height during childhood. A careful follow-up is recommended. If further catch-up growth is not observed, they might be candidates to $\mathrm{GH}$ treatment.

\section{Declaration of interest}

The authors declare that there is no conflict of interest that could be perceived as prejudicing the impartiality of this review.

\section{Funding}

This research did not receive any specific grant from any funding agency in the public, commercial or not-for-profit sector.

\section{References}

1 WHO. WHO: recommended definitions, terminology and format for statistical tables related to the perinatal period and use of a new certificate for cause of perinatal deaths. Modifications recommended by FIGO as amended October 14, 1976. Acta Obstetricia et Gynecologica Scandinavica 197756 247-253. (doi:10.3109/00016347709162009)

2 Blencowe H, Cousens S, Chou D, Oestergaard M, Say L, Moller AB, Kinney M \& Lawn J. Born too soon: the global epidemiology of 15 million preterm births. Reproductive Health 201310 (Supplement 1) S2. (doi:10.1186/1742-4755-10-S1-S2)

3 Platt MJ. Outcomes in preterm infants. Public Health 2014128 399-403. (doi:10.1016/j.puhe.2014.03.010)

4 Messerschmidt A, Olischar M, Birnbacher R, Weber M, Pollak A \& Leitich H. Perinatal outcome of preterm infants $<1500 \mathrm{~g}$ after IVF pregnancies compared with natural conception. Archives of Disease in Childhood: Fetal and Neonatal Edition 201095 F225-F229. (doi:10.1136/adc.2009.165761)

5 Lawn JE, Davidge R, Paul VK, von Xylander S, de Graft Johnson J, Costello A, Kinney MV, Segre J \& Molyneux L. Born too soon: care for the preterm baby. Reproductive Health 201310 (Supplement 1) S5. (doi:10.1186/1742-4755-10-S1-S5)

6 Nguyen TH, Larsen T, Engholm G \& Moller H. Evaluation of ultrasound-estimated date of delivery in 17450 spontaneous singleton births: do we need to modify Naegele's rule? Ultrasound in Obstetrics and Gynecology 199914 23-28. (doi:10.1046/j.14690705.1999.14010023.x)

7 Committee on Obstetric Practice. American Institute of Ultrasound in Medicine; Society for Maternal-fetal Medicine. Committee opinion $n^{\circ}$ 611: method for estimating due date. Obstetrics and Gynecology 2014124 863-866. (doi:10.1097/01. AOG.0000454932.15177.be)

8 Ballard JL, Khoury JC, Wedig K, Wang L, Eilers-Walsman BL \& Lipp R. New Ballard Score, expanded to include extremely premature infants. Journal of Pediatrics 1991119 417-423. (doi:10.1016/S0022-3476(05)82056-6)

9 Engle WA. A recommendation for the definition of 'Late preterm' (Near term) and the birth weight-gestational age classification system. Seminars in Perinatology 200630 2-7. (doi:10.1053/j. semperi.2006.01.007)

10 Blencowe H, Cousens S, Oestergaard MZ, Chou D, Moller AB, Narwal R, Adler A, Vera Garcia C, Rohde S, Say L et al. National, regional, and worldwide estimates of preterm birth rates in the year 2010 with time trends since 1990 for selected countries: a systematic analysis and implications. Lancet $20123792162-2172$. (doi:10.1016/S0140-6736(12)60820-4)

11 Smith LK, Draper ES \& Field D. Long-term outcome for the tiniest or most immature babies: survival rates. Seminars in Fetal and Neonatal Medicine 201419 72-77. (doi:10.1016/j. siny.2013.11.002)

12 Eide MG, Oyen N, Skjaerven R, Nilsen ST, Bjerkedal T \& Tell GS. Size at birth and gestational age as predictors of adult height and weight. Epidemiology 200516 175-181. (doi:10.1097/01. ede.0000152524.89074.bf)

13 Nagasaka M, Morioka I, Yokota T, Fujita K, Kurokawa D, Koda T, Shibata A, Yamada H, Ito Y, Uchino E et al. Incidence of short stature at 3 years of age in late preterm infants: a population-based study. Archives of Disease in Childhood 2015100 250-254. (doi:10.1136/archdischild-2014-307045)

14 Neubauer V, Fuchs T, Griesmaier E, Pupp-Peglow U \& KiechlKohlendorfer U. Comparing growth charts demonstrated significant deviations between the interpretation of postnatal growth patterns in very preterm infants. Acta Paediatrica 2016 105 268-273. (doi:10.1111/apa.13175)

15 Rao SC \& Tompkins J. Growth curves for preterm infants. Early Human Development 200783 643-651. (doi:10.1016/j. earlhumdev.2007.07.008)

16 Bertino E, Milani S, Fabris C \& De Curtis M. Neonatal anthropometric charts: what they are, what they are not. Archives of Disease in Childhood: Fetal and Neonatal Edition 200792 F7-F10. (doi:10.1136/adc.2006.096214)

17 Villar J, Knight HE, de Onis M, Bertino E, Gilli G, Papageorghiou AT, Ismail LC, Barros FC \& Bhutta ZA. Conceptual issues related to the construction of prescriptive standards for the evaluation of postnatal growth of preterm infants. Archives of Disease in Childhood 201095 1034-1038. (doi:10.1136/ adc.2009.175067)

18 Pereira-da-Silva L \& Virella D. Is intrauterine growth appropriate to monitor postnatal growth of preterm neonates? BMC Pediatrics 201414 14. (doi:10.1186/1471-2431-14-14)

19 Fenton AC \& Kim JH. A systematic review and meta-analysis to revise the Fenton growth chart for preterm infants. BMC Pediatrics 201313 1-13. (doi:10.1186/1471-2431-13-1)

20 Wang Z \& Sauve RS. Assessment of postneonatal growth in VLBW infants: selection of growth references and age adjustment for prematurity. Canadian Journal of Public Health 199889 109-114. 
21 Chauhan SP, Charania SF, McLaren RA, Devoe LD, Ross EL, Hendrix NW \& Morrison JC. Ultrasonographic estimate of birth weight at 24 to 34 weeks: a multicenter study. American Journal of Obstetrics and Gynecology 1998179 909-916. (doi:10.1016/S00029378(98)70188-7)

22 Carranza Lira S, Haro Gonzalez LM \& Biruete Correa B. Comparacion entre la medicion clinica y ultrasonografica para estimar el peso fetal en la fase activa del trabajo de parto: nueva formula para el calculo clinico. Ginecología y Obstetricia de México $2007 \mathbf{7 5} 582-587$.

23 Merialdi M, Widmer M, Gulmezoglu AM, Abdel-Aleem H, Bega G, Benachi A, Carroli G, Cecatti JG, Diemert A, Gonzalez R et al. WHO multicentre study for the development of growth standards from fetal life to childhood: the fetal component. BMC Pregnancy Childbirth 201414 157-165. (doi:10.1186/1471-2393-14-157)

24 Niklasson A \& Albertsson-Wikland K. Continuous growth reference from 24 th week of gestation to 24 months by gender. BMC Pediatrics 20088 8-32. (doi:10.1186/1471-2431-8-8)

25 Gardosi J. Customised assessment of fetal growth potential: implications for perinatal care. Archives of Disease in Childhood: Fetal and Neonatal Edition 201297 F314-F317. (doi:10.1136/ fetalneonatal-2012-301708)

26 WHO Multicentre Growth Reference Study Group. WHO Child Growth Standards based on length/height, weight and age. Acta Paediatrica Supplement 2006450 76-85.

27 Villar J, Giuliani F, Bhutta ZA, Bertino E, Ohuma EO, Ismail LC, Barros FC, Altman DG, Victora C, Noble JA et al. Postnatal growth standards for preterm infants: the Preterm Postnatal Follow-up Study of the INTERGROWTH-21(st) Project. Lancet Global Health 20153 e681-e691. (doi:10.1016/S2214-109X(15)00163-1)

28 Villar J, Papageorghiou AT, Pang R, Salomon LJ, Langer A, Victora C, Purwar M, Chumlea C, Qingqing W, Scherjon SA et al. Monitoring human growth and development: a continuum from the womb to the classroom. American Journal of Obstetrics and Gynecology 2015213 494-499. (doi:10.1016/j.ajog.2015.07.002)

29 Carberry AE, Gordon A, Bond DM, Hyett J, Raynes-Greenow CH \& Jeffery HE. Customised versus population-based growth charts as a screening tool for detecting small for gestational age infants in low-risk pregnant women. Cochrane Database of Systematic Reviews 2014 CD008549. (doi:10.1002/14651858.CD008549.pub3)

30 Murphy VE, Smith R, Giles WB \& Clifton VL. Endocrine regulation of human fetal growth: the role of the mother, placenta, and fetus. Endocrine Reviews 200627 141-169. (doi:10.1210/er.2005-0011)

31 Pfister KM \& Ramel SE. Linear growth and neurodevelopmental outcomes. Clinics in Perinatology 201441 309-321. (doi:10.1016/j. clp.2014.02.004)

32 Huysman WA, de Ridder M, de Bruin NC, van Helmond G, Terpstra N, Van Goudoever JB \& Sauer PJ. Growth and body composition in preterm infants with bronchopulmonary dysplasia. Archives of Disease in Childhood: Fetal and Neonatal Edition 200388 F46-F51. (doi:10.1136/fn.88.1.F46)

33 Niklasson A, Engstrom E, Hard AL, Wikland KA \& Hellstrom A. Growth in very preterm children: a longitudinal study. Pediatric Research 200354 899-905. (doi:10.1203/01. PDR.0000091287.38691.EF)

34 Sauer PJ. Can extrauterine growth approximate intrauterine growth? Should it? American Journal of Clinical Nutrition $2007 \mathbf{8 5}$ 608S-613S.

35 Rugolo LMSS. Growth and developmental outcomes of the extremely preterm infant. Journal of Pediatrics 200581 S101-S110. (doi:10.2223/JPED.1309)

36 Sices L, Wilson-Costello D, Minich N, Friedman H \& Hack M. Postdischarge growth failure among extremely low birth weight infants: Correlates and consequences. Paediatrics and Child Health 200712 22-28.
37 Clark RH, Thomas P \& Peabody J. Extrauterine growth restriction remains a serious problem in prematurely born neonates. Pediatrics 2003111 986-990. (doi:10.1542/peds.111.5.986)

38 Cooke RJ, Ainsworth SB \& Fenton AC. Postnatal growth retardation: a universal problem in preterm infants. Archives of Disease in Childhood: Fetal and Neonatal Edition 200489 F428-F430. (doi:10.1136/adc.2001.004044)

39 Shah PS, Wong KY, Merko S, Bishara R, Dunn M, Asztalos E $\&$ Darling PB. Postnatal growth failure in preterm infants: ascertainment and relation to long-term outcome. Journal of Perinatal Medicine 200634 484-489. (doi:10.1515/JPM.2006.094)

40 Lin Z, Green RS, Chen S, Wu H, Liu T, Li J, Wei J \& Lin J. Quantification of EUGR as a Measure of the Quality of Nutritional Care of Premature Infants. PLOS ONE 201510 e0132584. (doi:10.1371/journal.pone.0132584)

41 Hack M, Schluchter M, Cartar L, Rahman M, Cuttler L \& Borawski E. Growth of very low birth weight infants to age 20 years. Pediatrics 2003112 e30-e38. (doi:10.1542/peds.112.1.e30)

42 Fewtrell MS, Cole TJ, Bishop NJ \& Lucas A. Neonatal factors predicting childhood height in preterm infants: evidence for a persisting effect of early metabolic bone disease? Journal of Pediatrics 2000137 668-673. (doi:10.1067/mpd.2000.108953)

43 Vohr BR, Bell EF \& Oh W. Infants with bronchopulmonary dysplasia. Growth pattern and neurologic and developmental outcome. American Journal of Diseases of Children 1982136 443-447. (doi:10.1001/archpedi.1982.03970410061015)

44 Wheater M \& Rennie JM. Poor prognosis after prolonged ventilation for bronchopulmonary dysplasia. Archives of Disease in Childhood: Fetal and Neonatal Edition 199471 F210-F211. (doi:10.1136/fn.71.3.F210)

45 Gibson AT, Pearse RG \& Wales JK. Growth retardation after dexamethasone administration: assessment by knemometry. Archives of Disease in Childhood 199369 505-509. (doi:10.1136/ adc.69.5_Spec_No.505)

46 Wood NS, Costeloe K, Gibson AT, Hennessy EM, Marlow N \& Wilkinson AR. The EPICure study: growth and associated problems in children born at 25 weeks of gestational age or less. Archives of Disease in Childhood: Fetal and Neonatal Edition $2003 \mathbf{8 8}$ F492-F500. (doi:10.1136/fn.88.6.F492)

47 Gutbrod T, Wolke D, Soehne B, Ohrt B \& Riegel K. Effects of gestation and birth weight on the growth and development of very low birthweight small for gestational age infants: a matched group comparison. Archives of Disease in Childhood: Fetal and Neonatal Edition 200082 F208-F214. (doi:10.1136/fn.82.3.F208)

48 Leger J, Limoni C \& Czernichow P. Prediction of the outcome of growth at 2 years of age in neonates with intra-uterine growth retardation. Early Human Development 199748 211-223. (doi:10.1016/S0378-3782(96)01855-5)

49 Edouard T, Trivin C, Lawson-Body E, Pinto G, Souberbielle JC $\&$ Brauner R. Extreme short stature after intrauterine growth retardation: factors associated with lack of catch-up growth. Hormone Research 200461 33-40. (doi:10.1159/000075195)

50 Tudehope DI. Human milk and the nutritional needs of preterm infants. Journal of Pediatrics 2013162 S17-S25. (doi:10.1016/j. jpeds.2012.11.049)

51 Thureen PJ. The neonatologist's dilemma: catch-up growth or beneficial undernutrition in very low birth weight infants-what are optimal growth rates? Journal of Pediatric Gastroenterology and Nutrition 200745 (Supplement 3) S152-S154. (doi:10.1097/01. mpg.0000302962.08794.62)

52 Goulart AL, Morais MB \& Kopelman BI. Impact of perinatal factors on growth deficits of preterm infants. Revista da Associação Médica Brasileira 201157 269-275. (doi:10.1590/S010442302011000300008)

53 Westerberg AC, Henriksen C, Ellingvag A, Veierod MB, Juliusson PB, Nakstad B, Aurvag AK, Ronnestad A, Gronn M, 
Iversen PO et al. First year growth among very low birth weight infants. Acta Paediatrica 201099 556-562. (doi:10.1111/j.16512227.2009.01667.x)

54 Farooqi A, Hagglof B, Sedin G, Gothefors L \& Serenius F. Growth in 10- to 12-year-old children born at 23 to 25 weeks' gestation in the 1990s: a Swedish national prospective follow-up study. Pediatrics 2006118 e1452-e1465. (doi:10.1542/peds.2006-1069)

55 Yesinel S, Aldemir EY, Kavuncuoglu S \& Yildiz H. Evaluation of growth in very low birth weight preterm babies. Turk Pediatri Arsivi 201449 289-298. (doi:10.5152/tpa.2014.1989)

56 Euser AM, de Wit CC, Finken MJ, Rijken M \& Wit JM. Growth of preterm born children. Hormone Research 200870 319-328. (doi:10.1159/000161862)

57 Finken MJ, Dekker FW, de Zegher F \& Wit JM. Long-term height gain of prematurely born children with neonatal growth restraint: parallellism with the growth pattern of short children born small for gestational age. Pediatrics 2006118 640-643. (doi:10.1542/peds.2006-0103)

58 Knops NB, Sneeuw KC, Brand R, Hille ET, den Ouden AL, Wit JM $\&$ Verloove-Vanhorick SP. Catch-up growth up to ten years of age in children born very preterm or with very low birth weight. $B M C$ Pediatrics 20055 26. (doi:10.1186/1471-2431-5-26)

59 Trebar B, Traunecker R, Selbmann HK \& Ranke MB. Growth during the first two years predicts pre-school height in children born with very low birth weight (VLBW): results of a study of 1320 children in Germany. Pediatric Research 200762 209-214. (doi:10.1203/PDR.0b013e3180ca7c5b)

60 Qvigstad E, Verloove-Vanhorick SP, Ens-Dokkum MH, Schreuder AM, Veen S, Brand R, Oostdijk W \& Ruys JH. Prediction of height achievement at five years of age in children born very preterm or with very low birth weight: continuation of catch-up growth after two years of age. Acta Paediatrica 199382 444-448. (doi:10.1111/j.1651-2227.1993.tb12719.x)

61 Chaudhari S, Otiv M, Hoge M, Pandit A \& Mote A. Growth and sexual maturation of low birth weight infants at early adolescence. Indian Pediatrics 200845 191-198.

62 Itabashi K, Mishina J, Tada H, Sakurai M, Nanri Y \& Hirohata Y. Longitudinal follow-up of height up to five years of age in infants born preterm small for gestational age; comparison to full-term small for gestational age infants. Early Human Development 2007 83 327-333. (doi:10.1016/j.earlhumdev.2006.07.002)

63 Monset-Couchard M \& de Bethmann O. Catch-up growth in 166 small-for- gestational age premature infants weighing less than $1000 \mathrm{~g}$ at birth. Biology of the Neonate $2000 \mathbf{7 8} 161-167$. (doi:10.1159/000014265)

64 Ford GW, Doyle LW, Davis NM \& Callanan C. Very low birth weight and growth into adolescence. Archives of Pediatrics and Adolescent Medicine 2000154 778-784. (doi:10.1001/ archpedi.154.8.778)

65 Ortiz Espejo M, Perez-Navero JL, Munoz-Villanueva MC \& Mercedes GC. Nutritional assessment in neonatal and prepubertal children with a history of extrauterine growth restriction. Early Human Development 201389 763-768. (doi:10.1016/j. earlhumdev.2013.06.003)

66 Rieger-Fackeldey E, Blank C, Dinger J, Steinmacher J, Bode H \& Schulze A. Growth, neurological and cognitive development in infants with a birthweight $<501 \mathrm{~g}$ at age 5 years. Acta Paediatrica 201099 1350-1355. (doi:10.1111/j.1651-2227.2010.01762.x)

67 Bracewell MA, Hennessy EM, Wolke D \& Marlow N. The EPICure study: growth and blood pressure at 6 years of age following extremely preterm birth. Archives of Disease in Childhood: Fetal and Neonatal Edition 200893 F108-F114. (doi:10.1136/ adc.2007.118596)

68 Pierrat V, Marchand-Martin L, Guemas I, Matis J, Burguet A, Picaud JC, Fresson J, Alberge C, Marret S, Roze JC et al. Height at
2 and 5 years of age in children born very preterm: the EPIPAGE study. Archives of Disease in Childhood: Fetal and Neonatal Edition 201196 F348-F354. (doi:10.1136/adc.2010.185470)

69 Karlberg J \& Albertsson-Wikland K. Growth in full-term smallfor-gestational-age infants: from birth to final height. Pediatric Research 199538 733-739. (doi:10.1203/00006450-19951100000017)

70 Sullivan MC, McGrath MM, Hawes K \& Lester BM. Growth trajectories of preterm infants: birth to 12 years. Journal of Pediatrics Health Care 200822 83-93. (doi:10.1016/j. pedhc.2007.02.008)

71 Bocca-Tjeertes IF, Kerstjens JM, Reijneveld SA, de Winter AF \& Bos AF. Growth and predictors of growth restraint in moderately preterm children aged 0 to 4 years. Pediatrics 2011128 e1187-e1194. (doi:10.1542/peds.2010-3781)

72 Persson I, Ahlsson F, Ewald U, Tuvemo T, Qingyuan M, von Rosen D \& Proos L. Influence of perinatal factors on the onset of puberty in boys and girls: implications for interpretation of link with risk of long term diseases. American Journal of Epidemiology 1999150 747-755. (doi:10.1093/oxfordjournals.aje.a010077)

73 Peralta-Carcelen M, Jackson DS, Goran MI, Royal SA, Mayo MS \& Nelson KG. Growth of adolescents who were born at extremely low birth weight without major disability. Journal of Pediatrics 2000136 633-640. (doi:10.1067/mpd.2000.104291)

74 Wehkalampi K, Hovi P, Dunkel L, Strang-Karlsson S, Jarvenpaa AL, Eriksson JG, Andersson S \& Kajantie E. Advanced pubertal growth spurt in subjects born preterm: the Helsinki study of very low birth weight adults. Journal of Clinical Endocrinology and Metabolism 201196 525-533. (doi:10.1210/jc.2010-1523)

75 Brandt I, Sticker EJ, Gausche R \& Lentze MJ. Catch-up growth of supine length/height of very low birth weight, small for gestational age preterm infants to adulthood. Journal of Pediatrics 2005147 662-668. (doi:10.1016/j.jpeds.2005.06.034)

76 Lazar L, Pollak U, Kalter-Leibovici O, Pertzelan A \& Phillip M. Pubertal course of persistently short children born small for gestational age (SGA) compared with idiopathic short children born appropriate for gestational age (AGA). European Journal of Endocrinology 2003149 425-432. (doi:10.1530/eje.0.1490425)

77 Verkauskiene R, Petraitiene I \& Albertsson Wikland K. Puberty in children born small for gestational age. Hormone Research in Paediatrics 201380 69-77. (doi:10.1159/000353759)

78 Odberg MD, Sommerfelt K, Markestad T \& Elgen IB. Growth and somatic health until adulthood of low birthweight children. Archives of Disease in Childhood: Fetal and Neonatal Edition 201095 F201-F205. (doi:10.1136/adc.2009.160614)

79 Weiler HA, Yuen CK \& Seshia MM. Growth and bone mineralization of young adults weighing less than $1500 \mathrm{~g}$ at birth. Early Human Development 200267 101-112. (doi:10.1016/S03783782(02)00003-8)

80 Doyle LW \& Anderson PJ. Adult outcome of extremely preterm infants. Pediatrics 2010126 342-351. (doi:10.1542/peds.20100710)

81 Saigal S, Stoskopf B, Streiner D, Paneth N, Pinelli J \& Boyle M. Growth trajectories of extremely low birth weight infants from birth to young adulthood: a longitudinal, population-based study. Pediatric Research 200660 751-758. (doi:10.1203/01. pdr.0000246201.93662.8e)

82 Hovi P, Andersson S, Jarvenpaa AL, Eriksson JG, Strang-Karlsson S, Kajantie E \& Makitie O. Decreased bone mineral density in adults born with very low birth weight: a cohort study. PLoS Medicine 20096 e1000135. (doi:10.1371/journal.pmed.1000135)

83 Roberts G, Cheong J, Opie G, Carse E, Davis N, Duff J, Lee KJ \& Doyle L. Growth of extremely preterm survivors from birth to 18 years of age compared with term controls. Pediatrics 2013131 e439-e445. (doi:10.1542/peds.2012-1135) 
84Doyle LW, Faber B, Callanan C, Ford GW \& Davis NM. Extremely low birth weight and body size in early adulthood. Archives of Disease in Childhood 200489 347-350. (doi:10.1136/adc.2002.025924)

85 Vaag AA, Grunnet LG, Arora GP \& Brons C. The thrifty phenotype hypothesis revisited. Diabetologia 201255 2085-2088. (doi:10.1007/s00125-012-2589-y)

86 Wells JC. The thrifty phenotype hypothesis: thrifty offspring or thrifty mother? Journal of Theoretical Biology 2003221 143-161. (doi:10.1006/jtbi.2003.3183)

87 Hales CN \& Barker DJ. The thrifty phenotype hypothesis: type 2 diabetes. British Medical Bulletin 200160 5-20. (doi:10.1093/ $\mathrm{bmb} / 60.1 .5$

88 Cutfield WS, Regan FA, Jackson WE, Jefferies CA, Robinson EM Harris M \& Hofman PL. The endocrine consequences for very low birth weight premature infants. Growth Hormone and IGF Research 200414 (Supplement A) S130-S135. (doi:10.1016/j. ghir.2004.03.028)

89 Miller JD, Wright NM, Esparza A, Jansons R, Yang HC, Hahn H \& Mosier HD Jr. Spontaneous pulsatile growth hormone release in male and female premature infants. Journal of Clinical Endocrinology and Metabolism 199275 1508-1513. (doi:10.1210/ jcem.75.6.1464656)

90 Wright NM, Northington FJ, Miller JD, Veldhuis JD \& Rogol AD Elevated growth hormone secretory rate in premature infants: deconvolution analysis of pulsatile growth hormone secretion in the neonate. Pediatric Research 199232 286-290. (doi:10.1203/00006450-199209000-00008)

91 Hansen-Pupp I, Lofqvist C, Polberger S, Niklasson A, Fellman V, Hellstrom A \& Ley D. Influence of insulin-like growth factor I and nutrition during phases of postnatal growth in very preterm infants. Pediatric Research 201169 448-453. (doi:10.1203/ PDR.0b013e3182115000)

92 Kajantie E. Insulin-like growth factor (IGF)-I, IGF binding protein (IGFBP)-3, phosphoisoforms of IGFBP-1 and postnatal growth in very-low-birth-weight infants. Hormone Research 200360 (Supplement 3) 124-130. (doi:10.1159/000074513)

93 Rowe DL, Derraik JG, Robinson E, Cutfield WS \& Hofman PL. Preterm birth and the endocrine regulation of growth in childhood and adolescence. Clinical Endocrinology 201175 661-665. (doi:10.1111/j.1365-2265.2011.04116.x)

94 Kistner A, Deschmann E, Legnevall L \& Vanpee M. Preterm born 9-year-olds have elevated IGF-1 and low prolactin, but levels vary with behavioural and eating disorders. Acta Paediatrica 2014103 1198-1205. (doi:10.1111/apa.12751)

95 Miles HL, Derraik JG, Chiavaroli V, Hofman PL \& Cutfield WS. Response to IGF-1 generation test in short prepubertal children born very preterm or at term. Hormone Research in Paediatrics 2015 84 298-304. (doi:10.1159/000439233)

96 van de Lagemaat M, Rotteveel J, Heijboer AC, Lafeber HN \& van Weissenbruch MM. Growth in preterm infants until six months postterm: the role of insulin and IGF-I. Hormone Research in Paediatrics 201380 92-99. (doi:10.1159/000351710)

97 Schreiner F, Gohlke B, Stutte S, Bartmann P \& Woelfle J. Growth hormone receptor $\mathrm{d} 3$-variant, insulin-like growth factor binding protein-1-575G/A polymorphism and postnatal catch-up growth: association with parameters of glucose homeostasis in former extremely low birth weight preterm infants. Growth Hormone and IGF Research 201020 201-204. (doi:10.1016/j. ghir.2010.01.002)

98 Guasti L, Silvennoinen S, Bulstrode NW, Ferretti P, Sankilampi U $\&$ Dunkel L. Elevated FGF21 leads to attenuated postnatal linear growth in preterm infants through GH resistance in chondrocytes. Journal of Clinical Endocrinology and Metabolism 201499 E2198-E2206. (doi:10.1210/jc.2014-1566)

99 Lafeber HN. Nutritional management and growth hormone treatment of preterm infants born small for gestational age. Acta Paediatrica Supplement 1997423 202-205; discussion 206. (doi:10.1111/j.1651-2227.1997.tb18416.x)

100 Qi W, Shen Q, Qiao Y, Wei Z, Wei Y \& Fan T. The impact of recombinant human growth hormone on growth and development of low weight premature infants. International Journal of Clinical and Experimental Medicine 20169 4983-4988.

101 Van Pareren Y, Mulder P, Houdijk M, Jansen M, Reeser M \& Hokken-Koelega A. Adult height after long-term, continuous growth hormone (GH) treatment in short children born small for gestational age: results of a randomized, double-blind, doseresponse GH trial. Journal of Clinical Endocrinology and Metabolism 200388 3584-3590. (doi:10.1210/jc.2002-021172)

102 Dahlgren J \& Wikland KA. Final height in short children born small for gestational age treated with growth hormone. Pediatric Research 200557 216-222. (doi:10.1203/01. PDR.0000148716.71231.81)

103 Clayton PE, Cianfarani S, Czernichow P, Johannsson G, Rapaport R \& Rogol A. Management of the child born small for gestational age through to adulthood: a Consensus Statement of the International Societies of Pediatric Endocrinology and the Growth Hormone Research Society. Journal of Clinical Endocrinology and Metabolism 200792 804-810. (doi:10.1210/ jc.2006-2017)

104 de Kort SW, Willemsen RH, van der Kaay DC, Duivenvoorden HJ $\&$ Hokken-Koelega AC. Does preterm birth influence the response to growth hormone treatment in short, small for gestational age children? Clinical Endocrinology 200970 582-587. (doi:10.1111/ j.1365-2265.2008.03484.x)

105 Boguszewski MC, Lindberg A \& Wollmann HA. Three-year growth response to growth hormone treatment in very young children born small for gestational age-data from KIGS. Journal of Clinical Endocrinology and Metabolism 201499 2683-2688. (doi:10.1210/ jc.2013-4117)

106 Boguszewski MC, Karlsson H, Wollmann HA, Wilton P \& Dahlgren J. Growth hormone treatment in short children born prematurely - data from KIGS. Journal of Clinical Endocrinology and Metabolism 201196 1687-1694. (doi:10.1210/jc.2010-1829)

107 Berndt C, Schweizer R, Ranke MB, Binder G \& Martin DD. Height, muscle, fat and bone response to growth hormone in short children with very low birth weight born appropriate for gestational age and small for gestational age. Hormone Research in Paediatrics 201482 81-88. (doi:10.1159/000358520)

108 Dahlgren J, Kristrom B, Niklasson A, Nierop AF, Rosberg S \& Albertsson-Wikland K. Models predicting the growth response to growth hormone treatment in short children independent of GH status, birth size and gestational age. BMC Medical Informatics and Decision Making 20077 40. (doi:10.1186/1472-6947-7-40)

109 de Ridder MA, Stijnen T \& Hokken-Koelega AC. Prediction model for adult height of small for gestational age children at the start of growth hormone treatment. Journal of Clinical Endocrinology and Metabolism 200893 477-483. (doi:10.1210/jc.2007-1381)

110 Garcia RA, Longui CA, Kochi C, Arruda M, Faria CD, Calliari LE, Monte O, Pachi PR \& Saenger P. First two years' response to growth hormone treatment in very young preterm small for gestational age children. Hormone Research 200972 275-280. (doi:10.1159/000245929)

Received 5 June 2016

Revised version received 25 October 2016

Accepted 1 November 2016 